\title{
THE SPF VALUE DETERMINATION OF EXTRACT AND SUNSCREEN LOTIO OF LIME RIND EXTRACT BY SPEKTROFOMETRI UV-VIS METHOD
}

\author{
Sri Rejeki ${ }^{1}$, Fahrun $\mathrm{Nisaa}^{2}$, Siwi Hastuti ${ }^{3}$ \\ ${ }^{1}$ Teknologi Farmasi, Prodi D3 Farmasi Poltekkes Bhakti Mulia, Sukoharjo \\ ${ }^{2}$ Teknologi Farmasi, Prodi D3 Farmasi Poltekkes Bhakti Mulia, Sukoharjo \\ ${ }^{3}$ Teknologi Farmasi, Prodi D3 Farmasi Poltekkes Bhakti Mulia, Sukoharjo \\ Corresponding author : Rejekisri1005@yahoo.co.id
}

\begin{abstract}
Lime (Citrus urantifolia) contains vitamin $\mathrm{C}$ and flavonoids which have antioxidant activity that can be used as a sunscreen. Antioxidants can repaire the effects of damage to human skin caused by free radicals which are the main factors in the aging process and damage to skin tissue. This purposes of this study were to determine the SPF value of ethanol extract of lime peel and lotion of lime peel extract. Firstly, lime fruit skin was extracted by remaceration method using $70 \%$ ethanol and followed by determination or SPF values, lotion formulated and tested for SPF values with UV-VIS Spectrophotometry. The results showed that SPF values of the ethanol extract of lime peel in various concentrations 100ppm, 150 pm, 200ppm, 250ppm and 300ppm were respectively $4.77 \pm 0.12 ; 10.17 \pm 0.01$; $27.05 \pm 0.02 ; 50.33 \pm 0.18 ; 80.54 \pm 0.49$. The result showed that SPF value of lime ethanol extract sunscreen lotio in 300ppm was $80.54 \pm 0.49$. Ethanol extract of lime fruit skin has the potential as a sunscreen.
\end{abstract}

Keywords : lime rind extract, sunscreen, lotio, SPF

\section{Introduction}

Sun radiation that affects the surface of the earth is energy in the form of electromagnetic waves. Sunbeam radiation reaches the surface of the earth and has to do with the reaction of the human body is ultraviolet / UV light ( $\lambda$ 200-400nm), visible light $(\lambda$ $400-760 \mathrm{~nm})$ and infrared light ( $\lambda$ more than $760 \mathrm{~nm})$. From several spectra of light reaching the earth's surface, UV light is a small part of the spectrum of sunbeam and light is less than $1 \%$ of the entire spectrum of sunbeam. Ultraviolet light is most dangerous to the skin because of the reaction it causes. Exposure to excessive ultraviolet radiation can cause skin disorders such as hyperpigmentation, sunburn, premature aging, black and scaly skin, even skin cancer (Purwanti, 2005).

Naturally the skin has tried to protect itself and the organs below it from the dangers of the sun's Ultraviolet rays, among others by forming skin pigment grains (melanin) which more or less reflect sunbeam. (Dirjen POM,1985).Sunscreen is a preparation that contains chemical compounds that can absorb, scatter or reflect solar rays that affect the skin so that it can be used to protect the function and structure of human skin from sun damage (FDA,2003).
Natural ingredients are safer to use and have fewer side effects than chemicals. Therefore the use of natural ingredients that can reduce sunbeam radiation and improve protection against the side effects of sun radiation on the skin is a focus in several studies (Yasin, 2017).

Lime fruit contains saponins, flavonoids and essential oils of citric acid, glucose, fat, essential oils, vitamin $\mathrm{C}$, calcium, phosphorus, sulfur and amino acids. Flavonoids from lime rind extract are used as a basis for determining the potential of sunscreen, because flavonoids have a conjugated aromatic benzene group which is able to absorb UV-A or UV$B$ rays which can cause adverse effects on the skin. Lime rind extract at concentrations of 100 ppm, 150 ppm, 200 ppm, $250 \mathrm{ppm}$, and $300 \mathrm{ppm}$ had SPF values respectively 4.4, 9.2, 11.08, 13.7 and 40.15 (Yasin, 2017).

Ethanolic extract of lime rind has antioxidant activity that can work by overcoming the effects of damage to human skin caused by free radicals which are the main factors in the aging process and damage to skin tissue. The presence of flavonoids from lime rind extract can be used as a reference to determine the potential of sunscreen. 
Sunscreen is a substance or material that can protect the skin against UV radiation. Cosmetic preparations for sunscreen are in various forms such as lotio to be applied to the skin, ointment or spray applied to the skin. The effectiveness of sunscreen preparation is based on Sun Protected Factor (SPF) value which describes the ability of sunscreen products to protect the skin from erythema (Stanfield, 2003).One of the most widely used sunscreen preparations is lotions, liquid preparations in the form of suspensions or oil emulsions in water, used as topical application.

Based on the mechanism, sunscreen is divided into two, physical blockers and chemical absorbers. Physical sunscreen works by reflecting / scattering UV radiation by forming an opaque layer on the surface of the skin. Chemical sunscreen works by absorbing UV radiation. The mechanism of chemical sunscreen action through photochemical reactions by absorbing UV light so that its penetration into the skin epidermis will be inhibited The effectiveness of sunscreen preparation is based on the determination of SPF (Sun Protected Factor) value that illustrate the ability of sunscreen products to protect the skin from erythema. SPF values can be determined in vitro and in vivo. Testing of UV absorption activity in vitro can be done by UV spectrophotometry technique measured on the wavelength of UV light (200-400nm) (Stanfield, 2003).

The purposes of this study was to determine the value of SPF extract of lime rind, formulate the ethanolic extract of lime into a sunscreen lotion and determine the value of SPF lime skin lotion (Citrus aurantifolia) as a sunscreen.

\section{Methods}

\section{Tool}

UV spectrophotometer (Hitachi U-2900, Japan), analytic balance (sonic), $\mathrm{pH}$ Universal (local), mixer (miyako).

\section{Material.}

Lime rind, dilute ethanol (technique), dilute ethanol(pa), HPMC (technique), glycerin (technique), propylengikol (technique), methyl paraben (technique), aquadest (technique).

\section{Step of Research}

1. Extraction

Lime fruit is taken from Sukoharjo. Fresh and dark green lime fruit rinded, cleaned, cut, dried and mashed into powder. Four hundred grams of lime rind powder was remaceration with 2 liters dilute ethanol as solvent, macerate evaporated with waterbath until a thick extract.

2. SPF value test for Lime Fruit Rind Extract Lime fruit rind extract (LFRE) was dissolved in dilute ethanol with a concentration of $100 \mathrm{ppm}$, 150ppm, 200ppm, 250ppm and 300ppm. Testing the SPF value is done by measuring the absorbance (A) every $5 \mathrm{~nm}$ in the wavelength range $290 \mathrm{~nm}$ to $320 \mathrm{~nm}$, calculated by the area under the curve (AUC). Calculation of area under the curve (AUC) between the length of two successive wavelengths using the formula:

$[\mathrm{AUC}] \mathrm{ba}=(\mathrm{Aa}+\mathrm{Ab}) / 2 \mathrm{xdPa} \neg \mathrm{b}$

$\Sigma \mathrm{AUC}=\mathrm{AUC1}+\mathrm{AUC2}+\mathrm{AUCn}$

Information :

Aa: Absorbance at a wavelength a nm

$\mathrm{Ab}$ : Absorbance at wavelength $\mathrm{b} \mathrm{nm}$

$\mathrm{dPa}-\mathrm{b}$ : Difference in wavelengths $\mathrm{a}$ and $\mathrm{b}$.

The SPF value is calculated by the formula as in the equation:

$\log \mathrm{SPF}=\left(\sum \mathrm{AUC}\right) /(\lambda \mathrm{n}-\lambda 1)$

Information :

$\sum$ AUC: The amount of absorbance from $\lambda 1$ to $\lambda \mathrm{n}$. $\lambda \mathrm{n}$ : The biggest wavelength $(320 \mathrm{~nm})$

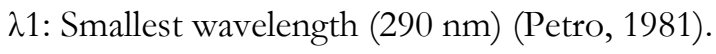

3. Lime Fruit Rind Extract Lotion Formulation

The lotion formula extracted from lime fruit rindwas presented in table 1. HPMC was dispersed in hot water until it expands, stirred with the mixer, propylene glycol, glycerin and nipagine solution was taken and stirred with the mixer until homogeneous. Lime fruit rind extract was inserted little by little while stirring with the mixer for 15 minutes.

Table 1.Formula of Sunscreen Lotion.

\begin{tabular}{ll}
\hline Formula & Composition \\
\hline LFRE & $0.3 \%$ \\
HPMC & $2 \%$ \\
Propilenglycol & $3 \%$ \\
Glycerin & $8 \%$ \\
Methyl Paraben & $0.2 \%$ \\
Aquadest ad & $100 \%$ \\
\hline
\end{tabular}


4. Lotion Evaluation Test

a. Observation of Organoleptis

Visual observation of odor, color, shape of lotion is carried out.

b. PH test

The $\mathrm{pH}$ of the lotion is measured using a universal $\mathrm{pH}$ indicator by means of the lotion inserted in the container and $\mathrm{pH}$ stick dipped in lotion. The $\mathrm{pH}$ of the lotion is known by comparing the color of the stick with a universal comparison $\mathrm{pH}$.

c. Spread Power Test

The LFRE lotion weighs $0.500 \mathrm{~g}$ placed on a round scale glass. On top of the lotions placed another round glass and a load of $100 \mathrm{~g}$, left for 1 minute, the spread area is noted.

d. Stickiness Test

The suction cup is placed between the glass objects, given a 500 gram load and left for 5 minutes, the load is taken, begin on and recording the time until the two glass objects was released. e. SPF Value Test of lotion

Test of lotion SPF value extract of lime fruit rind was carried out by making solution at a concentration of $300 \mathrm{ppm}$, absorbance was measured, calculated area under the curve (AUC) in the same way as testing the SPF value of LFRE

\section{Results and Discussion}

LFRE evaluation is done to identify the initial quality of the extract produced. Evaluation includes color, odor, yield and SPF EKBJN value. Extraction was carried out by remaceration method using dilute ethanol solvent because ethanol is semipolar so that it can extract non-polar and non-polar substances, remaceration method is chosen because it does not use direct heating, the results are more perfect than maceration, and simple. The results of the remmaceration of the LFRE amounted to $11.07 \% \mathrm{~b} / \mathrm{b}$

Table 2. Results of evaluation LFRE

\begin{tabular}{ll}
\hline Characteristics & research results \\
\hline Organolepstis & \\
- Color & Brownish yellow \\
- Smell & Lime specifict \\
Rendeman & $11.07 \% \mathrm{~b} / \mathrm{b}$ \\
SPF value & \\
-100ppm & $4.77 \pm 0.12$ \\
$-150 \mathrm{ppm}$ & $10.17 \pm 0.01$ \\
$-200 \mathrm{ppm}$ & $27.05 \pm 0.02$ \\
$-250 \mathrm{ppm}$ & $50.33 \pm 0.18$ \\
$-300 \mathrm{ppm}$ & $80.54 \pm 0.49$ \\
\hline
\end{tabular}

Volume 1 Issue 1 (2018)
The test results of SPF LFRE value at concentrations of $100 \mathrm{ppm}, 150 \mathrm{ppm}, 200 \mathrm{ppm}$, $250 \mathrm{ppm}$ and $300 \mathrm{ppm}$ were respectively $4.77 \pm 0.12$; $10.17 \pm 0.01 ; 27.05 \pm 0.02 ; 50.33 \pm 0.18$ and $80.54 \pm$ 0.49. Based on the Food and Drug Administration (FDA) SPF LFRE values at concentrations of $100 \mathrm{ppm}$ and $150 \mathrm{ppm}$ were included in the nimimal protection category because they have an SPF value between 2-12. SPF values at 200ppm were included in the medium protection category because they have SPF values between 12-30. The SPF LFRE value at a concentration of $250 \mathrm{ppm}$ and $300 \mathrm{ppm}$ has high protection because it has an SPF value of more than 30. The results of LFRE evaluation are presented in table 2 .

The formula used in making LFRE lotion is 0.3\% LFRE ; 2\% HPMC; 3\% propylene glycol; 8\% Glycerin; 0.2\% Methyl Parabenum and Aquadest to $100 \%$. Evaluation test was carried out on the 2 nd day because the constituent components in the lotion system for 2 days storage were well arranged. The lotion LFRE evaluation includes organoleptic, $\mathrm{pH}$ test, scattering power, stickiness and SPF value. The results evaluation of LFRE lotion were presented in table 3 .

Table 3. Test results evaluation of LFRE lotion

\begin{tabular}{|l|l|}
\hline \multicolumn{1}{|c|}{ Test parameters } & \multicolumn{1}{|c|}{ Test results } \\
\hline Organoleptic & Lotion \\
1. Shape & brownish yellow \\
2. Color & Spesific lime \\
3. Odor & Soft \\
4. Texture & Homogeneous \\
5. Homogenity & 5 \\
pH & 1.33 minutes \\
Stickiness Test & $28.04 \mathrm{~cm} 2$ \\
Spread Power & $60.79 \pm 3.65$ \\
SPF value &
\end{tabular}

The result of organoleptic evaluation of LFRE lotions was brownish yellow, typical lime odor, soft and homogeneous texture. Organoleptic evaluation is carried out to assess visual display of lotion. The results of organoleptic losip test were listed in table 3 .

The $\mathrm{pH}$ evaluation test purpose to determine the $\mathrm{pH}$ compatibility of the lotion with skin $\mathrm{pH}$, which is in the range of 4.5-7. The $\mathrm{pH}$ of the lotion is influenced by the composition of the formula. The results of the LFRE lotion $\mathrm{pH}$ test was 5 , the results was in accordance with the skin $\mathrm{pH}$ range so that when lotion was used it will be comfortable in the skin and does not cause irritation. 
Stickiness test was carried out to determine the time needed for the preparation to attach to the skin so that the effectiveness of the lotion in the therapeutic effect was known. The result of adhesion test of LFRE lotion was 1.33 seconds as listed in table 3. Stickiness test of lotion was affected by the HPMC correlation which was used as a lotion base.

The results of the LFRE lotion Spread Power test were $28.04 \mathrm{~cm}^{2}$. Spread power tests was performed to describe the equalization of lotion and the ability of lotion to spread when applied to the skin. Ease of deployment is related to the convenience of using lotions by consumers. The dispersion power of the lotions is affected by the concentration of HPMC, the greater the concentration of HPMC the power spreads the lotio. LFRE lotion scatter power test results are listed in table 3 .

Test the SPF value of LFRE lotion at 300ppm concentration was $60.79 \pm 3.65$. Based on the Food and Drug Administration (FDA) the LFRE lotion SPF value is included in high protection because it has an SPF value of more than 30. This value is lower than the SPF LFRE value at the same concentration.

\section{Conclusion}

1. SPF value of lime rind extract in various concentrations of $100 \mathrm{ppm}, 150 \mathrm{ppm}, 200 \mathrm{ppm}$, $250 \mathrm{ppm}$ and $300 \mathrm{ppm}$ were respectively at $4.77 \pm$ $0.12 ; 10.17 \pm 0.01 ; 27.05 \pm 0.02 ; 50.33 \pm 0.18$ and $80.54 \pm 0.49$.

2. The value of SPF lotion extract of lime rind at a concentration of $300 \mathrm{ppm}$ is $60.79 \pm 3.65$.

\section{References}

Dirjen POM. 1985. Formularium Kosmetika Indonesia. Jakarta: Depkes RI.

Food and Drug Administration (FDA). 2003. Guidance for Industry Photosafety Testing,
Pharmacology Toxycology Coordinating Committee in the Centre for Drug Evaluation and Research (CDER) at the FDA.

Garg, A., Anggarwal, D., Garg, S. Dan Singla, A.K. 2002. Spreading of Semisolid Formulations: An Update, Pharmacentical Technology

Petro, AJ. 1981. Correlation of Spectrophotometric Data With Sunscreen Protection Factors. International Journal. Cos. Sci: USA.

Purwanti, T., Erawati., T., Kurniawati, E. 2005. Penentuan Komposisi Optimal Bahan Tabir Surya Kombinasi Oksibenson-Oktildimetil PABA dalam Formula Vanishing Cream.Majalah Farmasi Airlangga.

Rejeki, S. 2014. Penggunaan Minyak Nyamplung (Callophyllum Inophyllum L),Sebagai Bahan Kosmetik Tabir Surya : Optimasi Formula Lotion Menggunakan Simplex Lattice Design dan Penetapan Harga SPF Secara In Vitro. Tesis. Fakultas Farmasi Universitas Gadjah Mada: Yogyakarta

Setiawan, T.2010. Uji Stabilitas Fisik Dan Penentuan Nilai SPF Krim Tabir Surya Yang Mengandung Ekstrak Daun The Hijau (Camellia SinensisL.), Oktil Metoksisinamat, Dan Titanium Dioksida.Skripsi. Depok: Fakultas Matematika dan Ilmu Pengetahuanalam, Universitas Indonesia.

Lestari, T. 2002.Hand and Body Lotion : Pengaruh Penambahan Nipagin, Nipasol dan Campuran Keduanya Terhadap Stabilitas Fisika dan Efektivitasnya sebagai Anti Jamur. Skripsi, Fakultas Farmasi Universitas Gajah Mada: Yogyakarta.

Yasin, Rifatul Adilah. 2017. Uji Potensi Tabir Surya Ektrak Kulit Buah Jeruk Nipis (CitrusAurantifolia)Secara In Vitro. Skripsi. Makassar: UIN Alauddin Makassar. 